\title{
Taxes and Competitiveness: How Much Competitive Is European Tax Competition?
}

Is taxation the tool for competitiveness? How can Europe become competitive in the post-BEPS era, and in the absence of corporate income tax harmonization? How can competitiveness help building communication and trust among tax players, NGOs, the media and the taxpayers? Is competitiveness equivalent to tax competition? These were some of the topics discussed on the Platform for Tax Good Governance at its meeting after the summer break. ${ }^{1}$

In recent years (since 2012), the European Commission has introduced in working papers and at meetings a connection between harmful tax competition, ${ }^{2}$ illegal State aid, including by secret rulings and the misuse of transfer pricing rules, and aggressive tax planning. In addition, in 2018, some EU Member States approved, or are in the process of approving, corporate income tax reforms, in order to be competitive again. ${ }^{3}$

These are not really surprising developments. EU Member States approved the Anti-Tax Avoidance Directive (ATAD) (which contains de minimis rules and, in some cases, optional rules). They unilaterally signed the Multilateral Instrument, ${ }^{4}$ i.e. without coordination in the EU, opting for different rules, and introducing different reservations. In the absence of corporate income tax base harmonization and consolidation, Member States look for possibilities that are compliant with the Base Erosion and Profit Shifting (BEPS) project, the Code of Conduct on Harmful Tax Competition, and State aid rules. Taken together, the BEPS project, the Code of Conduct and State aid rules plead for broad tax bases, and elimination of exceptional regimes. Both would help to curtail aggressive tax planning behaviour.
In this context, abolition of withholding taxes (as the Netherlands has announced) and reduction of tax rates (e.g. Belgium: 25.58\% in 2018 and $25 \%$ in 2020; Sweden: $21.4 \%$ in 2019 and $20.6 \%$ in 2021) are possibilities envisaged by Member States, accompanied by the implementation of the outcomes of the BEPS project and ATAD measures, and with the broadening of the tax base. These reforms will presumably promote competition, but not disparities or avoidance. Controlled foreign company (CFC) or switch-over rules, as well as the principal purpose test rule or the ATAD general anti-avoidance rule can in fact be applied by capital exporting jurisdictions in the case of non-genuine investment or where the principal purpose of cross-border investment is tax driven.

The competitiveness of companies in Europe-28 is currently related to the growth of digital firms, which have the highest annual revenue growth (14\%), far ahead of IT and telecommunication companies (3\%) and other multinationals $0.2 \%$.

\section{The Steady DeCrease IN TAX RATES AND OTHER TAX INCENTIVES, AND CONSTRAINTS ON COMPETITIVENESS}

The recent European Commission survey on tax policies in the European Union ${ }^{5}$ indicates that statutory corporate income tax rates have steadily decreased since 2003 , in the EU (28 Member States), the OECD (non-EU) and the BRIICS. The EU-28 average rate in the benchmark year (2003) is less than the OECD non-EU average and in the BRIICS: $28 \%$, against slightly over $30 \%$ in the OECD non-EU average, and slightly

\section{Notes}

Held on 12 Sept. 2018. See https://ec.europa.eu/taxation_customs/business/company-tax/tax-good-governance/platform-tax-good-governance_en\#meetings\%20documents.

See e.g. the meetings of the Platform on Tax Good Governance, since 16 Oct. 2013, https://ec.europa.eu/taxation_customs/business/company-tax/tax-good-governance/ platform-tax-good-governance_en\#meetings\%20documents. On harmful tax competition, see M. Noujen \& P. J. Wattel, Tax Competition and the Code of Conduct for Business Taxation, in Terra/Wattel European Tax Law, General Topics and Direct Taxation Vol. 1, 491-501(7th St. ed., P.J. Wattel, O. Marres \& H. Vermeulen eds, Wolters Kluwer 2018)

3 See the agenda of the Platform on Tax Good Governance Meeting, 12 Sept. 2018, and the reference to the Belgian and Swedish tax reforms at https://ec.europa.eu/taxation customs/business/company-tax/tax-good-governance/platform-tax-good-governance_en\#meetings\%20documents.

OECD, Multilateral Convention to Implement Tax Treaty Related Measures to Prevent Base Erosion and Profit Shifting (OECD Nov. 2016).

See https://ec.europa.eu/taxation_customs/business/company-tax/tax-good-governance/platform-tax-good-governance_en\#meetings\%20documents. 
over $32 \%$ in the BRIICS. In 2018, the difference between the EU-28 average rates and the OECD non-EU average and the BRIICS has increased: approximately $22 \%$ in the EU, slightly below 26\% in the OECD non-EU and 28\% in the BRIICS. Although there are other measures targeting tax competition (e.g. patent boxes, strengthening tax incentives), it is anticipated that the decrease in statutory corporate income tax rates will continue.

In turn, the debt-equity bias increased in most EU Member States between 2010 and 2016, and the research and development intensity targets for 2020 are ambitious for many EU-28 Member States. Tax incentives offered by EU Member States, Canada, Japan and the United States, among others, currently range from tax credits, tax exemptions, tax deductions, loss relief and a policy mix - often related to taxation of net income.

Moreover, according to the business perspective answers to a European Commission questionnaire, tax uncertainty in Europe is mainly related to bureaucracy; inconsistent treatment of situations and interpretation of international standards by tax authorities and courts; lengthy dispute resolution; and complexity and lack of clarity in tax law.

\section{URGENT PLEA FOR REFORM IN THE TAX HARMONIZATION DECISION-MAKING RULES}

On the basis of the above-mentioned data, the European Commission asked the members of the Platform for Tax Good Governance to answer a questionnaire, and using a digital tool (sli.do), collected the votes and individual answers. The first question related to the definition of a competitive tax system. Most members of the Platform concluded that it is a system promoting local innovation and growth (38\%); $25 \%$ stated that a competitive tax system is one attracting foreign direct investment; and $21 \%$ indicated that a competitive tax system ensures a level playing field. Certainty was chosen as the most significant element for a competitive tax system; $54 \%$ indicated that more internal tax competition is bad for EU competitiveness (against 34\% that indicated that it was good; $11 \%$ did not know), harmonization should be the priority for EU tax policy over the next five years, according to the majority of survey respondents.

The Platform for Tax Good Governance has been a forum for various stakeholders to debate the priorities for the EU tax policies - including the Member States, business representatives and NGOs. It is not clear whether the answers to some of the different questions are coherent, and what conclusions the Commission will draw from them.
While the definition chosen by most members (38\%) of the Platform, on a competitive tax system, relies on national and not on EU competitiveness - a system promoting local private sector growth (but 25\% indicated that a competitive tax system is one that attracts foreign direct investment; and $21 \%$ indicated that a competitive tax system ensures a level playing field), 54\% indicated that more internal tax competition is bad for EU competitiveness, and harmonization was most commonly indicated as a priority.

In this context, the ongoing internal tax competition in the EU reveals the distrust in the EU and among the Member States. The decrease in national tax rates and the fact that harmonization of tax bases is not moving forward, is related to the desire - or even the need - to keep national tax systems competitive.

Even if the corporate income tax base has been partially harmonized by the ATAD, many problems - including those related to transfer pricing in the EU - must be solved. The Arbitration Convention ${ }^{6}$ and Arbitration Directive $^{7}$ will only partially resolve the problem of litigation in the EU, and it remains to be seen how efficient they will be. This explains why further harmonization is felt to be necessary for EU competitiveness.

It is acknowledged that corporate income tax harmonization would require a much stronger EU budget, so that Member States losing competitiveness and revenue as a result of the harmonized tax, could still comply with the European and Monetary Union requirements. However, accepting that the majority of stakeholders agree that internal tax competition is bad for the EU, would require changes to the decision-making rules. Alternatively, Member States should seriously debate enhanced cooperation in direct tax matters.

The adoption of a majority rule for harmonization in taxes, combined with de minimis (flexible) rules (similarly to the ATAD and the Multilateral Instrument), allowing for unilateral amendments to legislation, and the evolution of transfer pricing using a profit split method, could be a way forward. Waiting for the OECD debate on the new international tax system reveals little ambition and will convert the need for competitiveness into a never-ending story of internal EU competition. It is the same old story. Yet, because it will likely shift the burden to other tax objects and other taxpayers, it further jeopardizes the EU Member States' national tax systems.

Ana Paula Dourado General Editor

\section{Notes}

EU Arbitration Convention (1990): Convention 90/436/EEC of 23 July 1990 on the Elimination of Double Taxation in Connection with the Adjustment of Profits of Associated Enterprises, OJ L225/10 (20 Aug. 1990).

EU Directive on Tax Dispute Resolution Mechanisms: Council Directive (EU) 2017/1852 of 10 Oct. 2017 on Tax Dispute Resolution Mechanisms in the European Union, OJ L265/1 (14 Oct. 2017). 